PF 2020 (75/1): 71-93

https://doi.org/10.32798/pf.648

\title{
KATJA BRANKAČKEC
}

Slovanský ústav AV ČR, v. v. i., Praha

e-mail: brankatschk@slu.cas.cz

ORCID 0000-0003-3551-8208

\section{VALENCE PREDIKÁTŮ Z OBLASTI „HNĚV” V HORNOLUŽICKÉ SRBŠTINĚ ${ }^{1}$}

\section{VALENCY OF THE PREDICATES WITH THE MEANING "HNĚV" [ANGER, UPSET, ANNOYANCE, WRATH] IN THE UPPER SORBIAN}

\begin{abstract}
The paper investigates the development of valency of the Upper Sorbian predicates expressing negative emotions. Based on data from the corpus Hotko, the two most frequent and largely synonymous roots -hněw- and -mjerz-are compared with respect to the scale of their meanings. The data suggest that -mjerz-is used more frequently in more recent texts, and that it expresses lower intensity of emotion more often than -hněw-. The meaning of individual predicates in the text can be specified with the help of several valency supplements, which often have a structure paralel to similar words in German or Czech.
\end{abstract}

KEYWORDS: negative emotions, development of valency, language contact

KLÍČOVÁ SLOVA: negativní emoce, vývoj valence, jazykový kontakt

SŁOWA KLUCZOWE: emocje negatywne, rozwój walencji, kontakt językowy

1 Následující článek vznikl v rámci přípravy grantového projektu k tématu „Semantics and Grammar of Predicates Denoting Negative Emotions in Selected West Slavic Languages and Russian”. Na projektu spolupracují badatelky ze Slovanského ústavu AV ČR a Ústavu českého jazyka a teorie komunikace FF UK. Na prŕpravě projektu spolupracovaly doc. Lucie Saicová Ř́malová, Ph.D., Karolína Skwarska, Ph.D., a Jana Kocková, Ph.D. Ráda bych jim poděkovala za četné cenné nápady a rady $\mathrm{k}$ teoretickému a metodickému řešení tématu. Za zbylé chyby a nedostatky zodpovídám sama. 


\section{Valence emočních predikátů - sémantika a syntax}

Dosavadní výzkum přinesl velký počet studií o sémantice a gramatice emočních predikátů v jazycích celého světa i ve slovanských jazycích (odkazy viz Kaczmarska $2019,9 n$.). Z nich je zřejmé, že jazykový materiál v oblasti emocí je velmi bohatý a že slovanské jazyky mají řadu společných rysů, ale v několika ohledech se také liší. Rozdíly jsou jak v rozsahu možných kontextů, ve kterých je možné slova používat (k tomu např. Kaczmarska 2019), tak i v gramatických jevech: různé jazyky preferují slovesný tvar místo adjektiva nebo naopak, používají různé valenční vzorce. Obě oblasti - gramatický popis i významová stránka slovní zásoby - spolu pochopitelně souvisejí.

V rámci tohoto článku není možné se zabývat otázkou, jak psychologie definuje emoce. Je však zřejmé, že myšlenky jsou klíčové při prožívání jakýchkoliv emocí, a že je tudíž nelze definovat nebo vysvětlit nezávisle na jazyku. Lidské emoce jsou tedy nutně propojeny s jazykem, ve kterém komunikujeme, i s kulturou, ve které žijeme a se kterou interagujeme (např. Trnka et al. 2018). Proto se nám zdá legitimní řešit otázku, co zahrnuje lužickosrbský „HNĚW”, pouze z hlediska lingvistiky.

Souvislosti sémantiky a valence sloves ve slovanských jazycích obecně se věnuje např. Kyselová (2017). Emoční slovesa zařazuje k procesním slovesům (ibid., s. 169n.), u kterých je charakteristické, že participant sice neiniciuje dění, ale dokáže ho částečně kontrolovat. Tato skutečnost se projevuje jednak $\mathrm{v}$ možnosti tvořit negovaný imperativ, jednak $\mathrm{v}$ existenci nereflexivních sloves (např. zuřit) a imperfektivních reflexivních sloves (zlobit se) vedle reflexivních perfektivních (rozzlobit se) (srov. také Wierzbicka 1995, s. 225).

Ve valenčních slovnících jsou zde zkoumaná slova zařazena do různých sémantických skupin: Např. Meškank (2009, s. 338n.; 343n.; 712; 730) zařazuje tranzitivní slovesa s kořeny -hněw- a -mjerz- bud' (1) do skupiny chování/pocity s konatelem v akuzativu (tzn. koho néco mrzí, zlobî) nebo (2) do skupiny jednáníl účinek ${ }^{2} \mathrm{~s}$ konatelem v nominativu (např. Ditě zlobí psa.). Zvratná slovesa patří podle Meškanka také ke slovesům chování/pocitů s doplněním sensa s předložkou $n a+$ A. Pro sloveso mjerzać so uvádí Meškank navíc ještě možnost doplnění sensa s př̀dložkou přrez + A, pro sloveso jednání/účinek mjerzać koho uvádí další

2 Pracovní pojem jednání/účinek zde používáme jako ekvivalent pro něm. pojem Verben des Sachverhalts Handeln/Einwirkung, jak ho používá Meškank (ibid.). Lze tomu rozumět jako akční sloveso podle klasifikace Daneše (Mluvnice 3, s. 33) nebo proces akční s více participanty (Daneš, Hlavsa 1987, s. 79) ve smyslu, že „Jde tedy o děj pojatý jako něčí (většinou záměrná) činnost, a proto participant $\mathrm{v}$ roli agentu bývá spojen se selektivním rysem [+ anim], nejčastěji zároveň [+ person]. Agens může mít rys [- anim] jen tehdy, jestliže element má (vzhledem k svým vlastnostem) s tímto rysem schopnost (z)působit nějakou změnu (...)" 
možnost doplnění propositum ${ }^{3}$ s předložkou $z+\mathrm{I}^{4}$ Také sloveso (za)złobić so je zařazeno do skupiny sloves chování/pocitů - ale pouze s konatelem v infinitivu a bez dalších doplnění (ibid., s. 419). Sloveso (roz)złobić jako tranzitivní sloveso Meškank neuvádí (srov. k tomu níže v kap. popisující data z korpusu).

Obdobné významy najdeme i v češtině, srov. např. slovesa zlobit (se) a jejich významovou klasifikaci ve slovníku Vallex ${ }^{5}$ (Lopatková et al. 2016, s. 589) s konatelem v nominativu (Meškankův význam 1) nebo akuzativu (2) a patiens v akuzativu (1) nebo nominativu (2) ${ }^{6}$. Obě tato slovesa jsou ve Vallexu (ibid.) označena jako psych verbs, zvratné sloveso je označeno jako mental action; to může mít patiens s předložkou $n a+A$ a další doplnění přičiny (cause) vyjádřený pomocí předložek kvůli $+\mathrm{D}$, pro + A nebo $z a+\mathrm{A}$.

Údaje k uvedeným slovesům jsou ve slovníku Svozilové et al. (2005, s. 556) trochu odlišné: tranzitivní zlobit zde má 4 významy - Meškankův význam (1) s konatelem $v$ nominativu a patiens $v$ akuzativu je zde rozdělen do dvou skupin - s dalším doplněním čím, s čím a s doplněním čím, pro něco. U zvratného slovesa zlobit se uvádí tento slovník aktanty/doplnění na koho/co, nad čím, pro co, kvưli někomu/čemu. Dále jsou zde jako další významy uvedena zlobit se s něčím, někým a zlobit se s někým (hovorově ve významu 'být rozhádaný).

Svozilová et al. (2005, s. 82) uvádí pro české substantivum hněv vazby na někoho, nad něčím, kvưli něčemu; vůči někomu/něčemu; proti někomu/něčemu. Pro sloveso hněvat se uvádí dva významy: (1) na někoho; kvưli něčemu; na někoho kvưli něčemu; (2) s někým. Lopatková et al. (2016) toto sloveso nezpracovává.

Cílem mého článku není ucelený teoretický popis valence emočních predikátů, ale pokud možno co nejpreciznější popis daného materiálu. $V$ tomto př́spěvku užívám Meškankovu terminologii (2009), aniž bych tím chtěla tvrdit, že jeho interpretace je nutně správnější než jiné. Přestože uvádím práce o odlišných jazycích (lužické srbštině a češtině) a s odlišným teoretickým př́stupem ${ }^{7}$, myslím, že srovnání valenčních slovníků ukazuje, že sémantická interpretace emočních

3 V korpusu jsem však našla i př́íklady doplnění $z$ + I s tímto slovesem, kde nejde o propositum, ale o sensum - jednoznačně je tomu tak u zvratného slovesa, srov. níže.

4 Odpovídá české př̀edložce $s+\mathrm{I}$.

5 Sloveso hněvat (se) není v tomto slovníku zaznamenáno, sloveso mrzet je naopak zařazeno pouze jako mental action (Lopatková et al. 2016, s. 176) s konatelem v akuzativu, fakultativním adresátem s předložkou na $+\mathrm{L}$ a patientem vyjádřeným nominativem nebo vedlejší větou. Zvratné sloveso mrzet se je ve Vallexu (ibid.) označeno rovněž jako mental action s konatelem $\mathrm{v}$ nominativu a patientem s předložkou $n a+$ A nebo nad $+\mathrm{I}$.

6 Jako třetí význam uvádí Lopatková et al. (ibid.) 'špatně fungovat'.

7 To jsou v př́padě Vallexu (Lopatková et al. 2016, 17n.) funkční generativní popis a u Meškanka (2019, s. 13n.) model kombinující valenci, dependenci a pádovou gramatiku dle germanisty Engela (1996). Teoretickým základem slovníku Svozilové et al. (2005, s. 7n.) je dvourovinná valenční syntax s jistými zjednodušeními, užívá se Český národní korpus (ibid., s. 9). Lexémy zde nejsou sémanticky klasifikovány, aktanty nejsou specifikovány podle sémantických rolí. 
lexémů není jednoznačná ${ }^{8}$ a i při snaze o vyhýbání se subjektivizmu (Lopatková et al. 2016, s. 19) nakonec podléhá subjektivním jazykovým úsudkům.

\section{Ustálenost valenčních vzorů: jazykový materiál a metody analýzy}

$\mathrm{V}$ tomto článku se věnujeme spisovné hornolužické srbštině. Základem je empirický výzkum materiálu z korpusu Hotko (ČNK). Jedná se o diachronní korpus s texty z let 1820 až 2010 o objemu cca 44,4 mil. pozic ${ }^{9}$.

Lužická srbština je menšinový jazyk, v kontaktu s němčinou jako úředním jazykem je nepřetržitě od středověku do současnosti. Přibližně v první polovině 20. stol. se vyvinul totální bilingvismus, tzn. všichni mluvčí (až na některé děti mladší než cca 4 roky) ovládají i němčinu aktivně a plynule.

Je třeba si uvědomit, že se nejedná o plně vyvinutý standardní jazyk (srov. např. Schuster-Šewc 1973, s. 220n.). Psaná hornolužická srbština začala vyvíjet naddialektální standard přibližně od 18. stol. (Faska 1998, s. 135-141), širšího rozsahu použití a stabilnější jazykové normy dosáhla až v druhé polovině 19. stol., kdy vyšly rozsáhlé slovníky a kodifikační gramatiky (srov. k tomu též Faska 1998, s. 167-177; Meškank 2009, s. 178n.; Wölke 2005).

Většina materiálu zahrnutého do korpusu Hotko vznikla na základě těchto norem. Je však v něm zřejmá nestabilita $\mathrm{v}$ oblasti syntaxe ${ }^{10}-$ mnohdy konkurují některé vazby s alternativními, které jsou kalky z němčiny (srov. Faßke 1981, s. 30n.; Meškank 2009, s. 179n.; 210; Brankačkec 2017, s. 106; 123n., Brankačkec et al. 2019). Proto je vhodné analyzovat materiál z diachronního hlediska, rozdělit korpus do časových úseků a při analýze dbát na období vzniku daných textů.

Pro účely této analýzy jsem se rozhodla rozdělit data do tří období: 19. století (1820-1900), období předválečné (1901-1945), období poválečné (1946-1980) a období nejmladší (1981-2010). Tím se snažím dosáhnout toho, aby př́íkladů nebylo pro statistickou analýzu př́liš málo ${ }^{11}$, a zároveň zohlednit vývoj hornolužického spisovného jazyka (srov. Brankačkec et al. 2019, s. 74n.; 86n.).

\footnotetext{
8 Mám na mysli zejména různé zařazení zvratného a nezvratného slovesa ve Vallexu vs. zařazení do stejné sémantické skupiny u Meškanka (viz výše).

$9 \quad \mathrm{Z}$ analýzy jsem vyloučila slovníky a terminologické př́ručky, a tak jsem pracovala s korpusem o rozsahu téměř 38,8 mil. pozic.

10 Je ale důležité si uvědomit, že normativní valenční slovník lužické srbštiny vyšel až v roce 2009.

11 Tato statistická analýza byla provedena především pomocí absolutní (počet výskytů) i relativní frekvence (instances per million $=$ i. p. m.) a v některých př́padech i procentuálním počítáním (podíl různých doplnění na celkovém počtu příkladů s tímto kořenem). Navíc jsem spočítala konfidenční intervaly dle Wilsona (Wallis 2013), srov. také Brankačkec et al. (2019, s. $88 n$.).
} 
V korpusu Hotko najdeme i metajazykovou publikaci Z labyrinta serbšćiny (Pohončowa et al. 2009), v níž je př́íspěvek o valenci sloves hněwać so/mjerzać so obsahující 13 př́íkladů z konkordance ,.* hněw.*” a 23 z konkordance „.. mjerza.*”:

Wobě tutej słowjesy, potajkim so mjerzać a so hněwać stej po cyłej Hornjej Łužicy rozšěrjenej, móžno je, zo wužiwa so so hněwać trochu husćišo, po woznamje so wonej njerozeznawatej. Ale wšudźom rěka serbsce, zo so na něšto hněwamy abo na něšto mjerzamy: Mjerzam so hižo wěčnje na tebje a na twoju njerodu, hněwamy so na pancate wjedro a na njedypkowneho listonoša ${ }^{12}$.

Z konkordance jsem tyto prríklady vyloučila - stejně jako zápisy ve slovnících a seznamy slov v lingvistických textech časopisů (srov. také pozn. 9).

Výrok v uvedeném citátu, že význam kořenů - mjerz-a - hněw- je stejný, se však nezdá po analýze valenčních vzorů (srov. níže) zcela korektní: podíl substantivních vazeb se „základni”" vazbou na koho/što je u kořene -hněw- signifikantně vyšší, u kořene -mjerz- je okrajový ${ }^{13}$. To by mohl být náznak drobných významových rozdílů těchto dvou kořenů, potenciálně souvisejících s kontaktem $\mathrm{s}$ němčinou. Německé ärger- má dva základní významy (DUDEN):

1) bewusstes, von starker Unlust und [aggressiver] innerer Auflehnung geprägtes [erregtes] Erleben [vermeintlicher] persönlicher Beeinträchtigung, besonders dadurch, dass etwas nicht ungeschehen zu machen, nicht zu ändern ist; Aufgebrachtsein, heftige Unzufriedenheit, [heftiger] Unmut, Unwille, [heftige] Verstimmung, Missstimmung

2) ärgerliches Erlebnis oder Gesamtheit ärgerlicher Erlebnisse; Verdruss, Unannehmlichkeit[en], Schererei[en] ${ }^{14}$

Německý kořen ärger- může mít valenční doplnění vyjádřeno především pomocí předložky über 'nad, o, přes' (srov. např. VALBU).

Ve většině slovanských jazyků pokrývá kořen -hněw- hlavně význam první, srov. např. definici u Mikołajczuk (1999, s. 32):

podstawową funkcją gniewu jest sprzeciw wobec tego, co jednostka subiektywnie uznaje za zło (wobec wyrządzonej jej krzywdy, przeszkody w działaniu itp.). Funkcja ta ma więc charakter obronny, spełnia się w pierwotnej sytuacji walki (dążenie do

12 Obě tato slovesa tedy so mjerzać a so hněwać jsou rozšířena po celé Horní Lužici, je možné, že se používá so hněwać trochu častěji, významově se neliší. Ale všude říkají lužickosrbsky, že se na něšto hněwamy nebo na něšto mjerzamy: Mjerzam so už věčně na tebe a na tvůj nepořádek, hněwamy so na deštivé počasí a na zpožděného listonoše. (přel. KB)

13 Poměry u slovesných dokladů s těmito kořeny jsou si naopak podobnější.

14 1) vědomé, silnou nechuti a [agresivním] vnitřním protestem doprovázené [vyvolané] prožívání [zdánlivého] osobního omezení, zejména tím, že něco nelze změnit; rozčilenost, silná nespokojenost, [silná] rozmrzelost, nevole, [silné] rozladění, rozmrzelost

2) nemilý, nepř́ijemný zážitek nebo celek nemilých zážitků, frustrace, mrzutost, nepohodlí, nepř́ijemnost, potíž, starosti, opletačky, potahovačky. (přel. KB) 
zdobycia władzy) i uzasadnia ścisły związek między gniewem i agresją z jednej strony oraz gniewem i strachem, żalem, zmartwieniem, wstydem - z drugiej (...).

Gniew v polštině je „interaktivní”, pro významy typu ärger2 používá polština jiné kořeny:

(1) Jestem zły, że jest zła pogoda. Vs. ${ }^{\star}$ Gniewam się, że jest zła pogoda.

Naopak v němčině - a stejně tak i v hornolužické srbštině - je možná věta typu:

(2) Ich ärgere mich über das schlechte Wetter. Das schlechte Wetter ist ärgerlich.

(3) Te špatne wjedro mje mjerza/hněwa. Te špatne wjedro je mjerzace/wobužne.

(4) Mjerzam so na te špatne wjedro. ?Mjerzam so přez te špatne wjedro. ${ }^{15}$

$\mathrm{V}$ analýze valenčních vazeb najdeme indicie, že význam německého ärger2 je častěji zastoupen kořeny -mjerz- a -wobuz/ž- než dalšími kořeny, ale ani u - hněwtento význam není vyloučen (srov. níže).

Kořen - hněw - ale odpovídá částečně i německému Zorn a Wut - to lze mj. usoudit podle častého používání tohoto kořenu (hlavně jako substantivum) v Bibli ${ }^{16}$ (srov. Brankačkec, Kocková 2020). Tyto dva německé kořeny mají možnost valenčního doplnění s předložkou auf 'na' (VALBU) - jde zde tedy o paralelu k lužickosrbské - a obecně západoslovanské (srov. např. Svozilová et al. 2005; výše) vazbě s předložkou na + A. České valenční slovníky však uvádějí více možnosti vazeb se slovesy této emoce (viz výše).

Popsaná situace dovoluje formulovat tezi, že různá doplnění velmi široce používaných kořenů - hněw- a -mjerz- slouží i $\mathrm{k}$ upřesnění významu - a to $\mathrm{v}$ souhře $s$ jazykovým kontaktem $s$ němčinou. Upřesnění významu se $\mathrm{v}$ textech samozřejmě neděje pouze pomocí valence (srov. pozn. 22).

\section{Predikáty s významem „HNĚV” v hornolužické srbštině}

V hornolužické srbštině je několik kořenů, které můžou vyjadřovat „HNĚV” ve výše nastíněném smyslu. Jsou to především -hněw-, -mjerz-, -wobuz/ž-, -złob-, -złosć/t-. Sémantický rozsah každého $\mathrm{z}$ těchto kořenů se liší - jsou to tedy jen částečná synonyma. Ojedinělé př́íklady (v korpusu 10×, 0,26 i. p. m. ,items per million') obsahují lexém s kořenem -sćekt- vyjadřujícím negativní emoci 'vztek', v zásadě je tento kořen ale používán pro význam choroby 'vzteklina' (dalších 37 příkladů $\mathrm{v}$ korpusu) ${ }^{17}$. Další přibližně synonymní a často metaforické kořeny jako (roz)hor-,

15 Srov. citát z Pohončowé et al. (2009) výše.

16 Lužická srbština je zde $\mathrm{v}$ kontrastu zejména s češtinou, kde je kořen - $h n e ̌ v$ - okrajový, srov. Brankačkec, Kocková (2020).

17 Tento kořen je $\mathrm{v}$ korpusu doložen jen jako adjektivum sćekły nebo jako substantivum sćekłosć. Žádný z těchto př́kladů nemá další doplnění. 
(roz)pyr-a -njemdr- ${ }^{18}$ se vyskytují často v kombinaci s kořenem -hněw-a odpovídají výhradně intenzivnějším emocím, jako je vyjadřují něm. Wut, Zorn nebo ärgerl.

Kořen -złob- je doložen v korpusu Hotko (kromě slovníků) 1152×, to je 29,7 i. p. m. ${ }^{19}$ Kořen -złosć/t- je doložen $1227 \times$, tj. 31,6 i. p. m. ${ }^{20}$ Kořen -wobuz/žje doložen $543 \times$, tj. 14 i. p. m. ${ }^{21}$

Podrobnějšíanalýza těchto dalších kořenů (zejména -złob-,-njemdr-a-wobuz-) v porovnání s výše zmíněnými by bohužel znamenala neúměrné rozšiřrení tohoto př́spěvku. V následujících podkapitolách se zaměřím na dva nejčastější kořeny, -hněw- a -mjerz-, a porovnám jejich užívání s důrazem na valenci v diachronním pohledu.

\section{Kořen -hněw-}

Lexémům s tímto kořenem jsme se věnovali v textu Brankačkec, Kocková (2020). V hornolužické srbštině je to produktivní kořen, který lze označit jako neutrální pro daný význam - lze ho používat jak pro nižší intenzitu emoce ,mrzet koho', tak i pro velmi silnou intenzitu, vztek ${ }^{\text {(22 }}$. Ve srovnání s jinými kořeny se vyskytuje nejčastěji, a to ve tvarech jmenných i slovesných. V korpusu je doložena široká

18 U kořenu -njemdr- 'vztek' převažuje adjektivum nebo participium - často v adjektivní funkci, substantiva nebo slovesa jsou méně častá: dotaz ,.*njemdr. ${ }^{*}$ " má v Hotku 1271 př́kladů (vyjma slovníky), tj. 28,65 i. p. m. - z toho je 210 slovesných tvarů (kromě participií a dějových substantiv).

19 U tohoto kořene převažují substantiva. Různé deriváty mají celkem tři valenční doplnění $(1 \times n a d+\mathrm{I}, 21 \times n a+\mathrm{A}, 1 \times$ preći $i w o+\mathrm{D})$. U sloves je nápadné, že téměř nejsou doložena slovesa jednání/ účinek - z 379 dokladů s finitním slovesem je jen 7 tohoto typu, většinou jde o sloveso rozzłobić koho. (To je markantní rozdíl oproti slovesu zlobit v češtině.) U sloves je vazba $n a+A$ zastoupena $83 \times$, dále jsou doloženy dla $+\mathrm{G}(3 \times)$, pře $+\mathrm{A}(2 \times)$, préćiwo $+\mathrm{D}(1 \times)$, nad $+\mathrm{I}(6 \times)$, přez $+\mathrm{A}(1 \times)$ a $z+\mathrm{I}(2 \times)$. Adjektiva a participia $\mathrm{s}$ tímto kořenem jsou doložena $\mathrm{v} 262$ př́kladech, nejčastěji participia $n / t$-ová rozzłobje$n y(80 \times)$ a zazłobjeny (101×). $\mathrm{Z}$ nich jsou 4 doplněny o sensum $(2 \times n a+\mathrm{A}$, précíwo $+\mathrm{D}$, préz $+\mathrm{A})$.

20 Tento kořen se od ostatních liší tím, že v korpusových textech nemá prefigované deriváty, nejsou doložena žádná doplnění a jen dva doklady se slovesy (złósćić so, złósćeć so). Silně převažuje substantivum złósć $(948 \times)$ a další substantiva (dohromady 7), dále jsou doložena adjektiva a adverbia $(270 \times)$, nejčastěji złóstny (188×) a złóstnje (44×), kromě toho złósćiwy $(22 \times)$ a złósćiwje (7×), vzácně złóstniwy $(9 \times)$.

21 U tohoto kořenu je sloveso doloženo jen vzácně (5×), nejčastější je adjektivum wobužny (243×), další adjektiva a adverbia jsou doložena $54 \times$, substantiva $241 \times$. Doplnění jsou doložena v 11 př́kladech, i zde převažuje $n a+\mathrm{A}(5 \times)$, doloženy jsou i G (być čeho wobužny, $1 \times)$, přre $+\mathrm{A}(1 \times)$, $w+\mathrm{L}(1 \times), z+\mathrm{I}(2 \times), n a d+\mathrm{I}(1 \times)$.

22 Srov. k tomu různá německá slova, pro která uvádí Jentsch et al. (1989/1991) jako ekvivalent slova s kořenem -hněw-, např.: Wutanfall, wütend werden, eine Stinkwut haben, wutbebend, erzürnen, zornentbrannt, zornig, zornbebend, böse werden, Bosheit, erbosen, grimmig machen, Grimm, Ingrimm, fuchsen, Groll, verbiestert, sich giften, Entrüstung, Unwillen, unwillig, Mißgunst, ungehalten, wurmen, verbittern, Verbitterung, Gereiztheit, verstimmen, verstimmt, voller Unmut, Verdruß, verdrießen, verärgern, Ärgernis, Ärger, ärgerlich, verschnupfen, Mißstimmung, Knatsch, Schererei, Unannehmlichkeiten. Není proto překvapivé, že je kořen -hněw-v textech 
škála derivátů (ibid.), celkem se kořen vyskytuje 4468×, tj. 115,2 i. p. m. Jako v jiných slovanských jazycích (Brankačkec, Kocková 2020, s. 40n.) v korpusu převažují - zejména $\mathrm{v}$ náboženských textech - tvary jmenné. Podíl substantiv s kořenem -hněw- je však menší, než je tomu v jiných slovanských jazycích (ibid.).

\section{Nejčastější vazby se substantivy s kořenem -hněw-}

Substantivum hněw a méně často i další substantiva s tímto kořenem (celkem $1821 \times, 47$ i. p. m.) jsou často užívána ve verbonominálních spojeních jako měć hněw, činić hněw. Převažují však vazby s plnovýznamovými slovesy, které $\mathrm{v}$ některých př́ípadech působí jako ustálené frazémy, např. Boži hněw na koho přińdźe, wusypać swój hněw na koho, sćahnyć něčeji hněw na so, wabić koho do hněwa, rěčé z hněwom, pokazać swój hněw, być połny hněwa, dusyć swój hněw, hnać koho do hněwa, puknyć so z hněwom, być komu k hněwu apod.

Role sensum ${ }^{23}$ je $v$ těchto vazbách vyjádřena méně často než v jiných konstrukcích, v korpusu jsem našla dohromady 128 př́kladů, kde navazuje doplnění o sensu hněvu. Valenční vazba užitého slovesa se často hodí i k substantivu hněw, tyto př́klady (nejčastěji se vyskytují v Bibli) jsem však počítala jako slovesné valenční vazby, srov.:

(5) Znowa so zapyri Knjezowy hněw na jeho lud, jeho zawostatk so zwohidźi. (2006, Swjate Pismo Stareho a Noweho Zakonja)

Jako valenci substantiva $s$ kořenem -hněw- jsem ji označila jen $v$ př́padech, kde lze vazbu přiřadit jednoznačně $\mathrm{k}$ substantivu, nap̌r.:

(6) [...], ale tež kóždy přistojny a rozomny čłowjek dyrbjał so zapyrić w sprawnym hněwje nad tak hrubym zmyslenju, tu wuprajenym. (1911, Katholski posot)

V tomto prípadě je obtížné přiřadit danou vazbu slovesu, protože se jedná o emoci člověka, která je zaměřena na určitý způsob chování, ne na konkrétní osobu. Proto zde není možné chápat předložku nijak prostorově. Přestože věty (5) a (6) jsou si tedy svou povrchovou strukturou velmi podobné, rozhodla jsem se pro různou interpretaci valenční struktury. $\mathrm{V}$ některých př́ípadech by interpretace valenční vazby se slovesem dokonce změnila smysl věty (resp. věta by se stala nesmyslnou), srov.:

často doplněn různými prostředky (adverbia jako trochu 'trochu', jara 'velmi', další, částečně synonymní adjektiva jako mjerzacy, njemdry, rozhorjeny), která význam upřesňují.

23 Dle Meškanka (2009, s. 32) je to „Sachverhalt, der im Zusammenhang mit einem Verhalten den Gegenstand des Empfindes oder Interesses zum Ausdruck bringt", to znamená je to „poměr věci, který v souvislosti s chováním vyjadřuje předmět pocitu nebo zájmu” (přel. KB). Kromě navazování, které zde popisuji, je téměř u všech predikátů z této významové oblasti možné vyjadřovat sensum pomocí vedlejší věty se spojkou $z o$ a indikativem nebo jiného typu vedlejší věty (relativní věty s hdyž apod.). Tento typ doplnění zde ponechávám stranou. 
(7) Tuž prošu Tebje, wostaj hněw a złoby na mnje, chcemoj so znjesć a budź zaso přeswědčeny, zo ja njejsym přećiwo Tebi a »Łužicy«, ale za Tebje a za »Łužicu«. (1909, Jakub Bart-Ćišinski, Zhromadźene spisy. 13. Listowanje, Budyšin 1978)

Valenční vazby se substantivem jsou u tohoto kořene v zásadě stejné jako vazby se slovesem, nejčastěji najdeme i zde vazbu na + A $(66 \times)$, a to jak v nejstarších, tak i v nejmladších textech, např.:

(8) Čim starši bu, ćim sylnišo rosćeše jeho hněw na Francózow. (1914, Mikławš Bjedrich-Radlubin, I. Plista. Žortna bjesada. II. Ducy z kowarnje. Humoristiski wobraz)

(9) Přewulkej stej hněw a hida na čłowjeka, kotryž je z wulkim wosobinskim zasadźenjom a zapalom po politiskim přewróće [...] (2010, Serbske nowiny)

Vazba $d l a+G$ je zde zastoupena $18 \times$, př́klady jsou doloženy v textech od roku 1966 do nejnovějších, převažují přitom př́klady z období od 90 . let 20. stol. Uvádím jeden $\mathrm{z}$ nejstarších dokladů z beletristického textu:

(10) Hłuboko w nim žerješe, kaž kisalina, jeho hněw dla njedawneho cofnjenja. (1974, Jan Wornar, Dypornak ma ptačka)

Vazba nad + I se substantivy je v korpusu zastoupena $14 \times$, a to především v publicistických textech ze začátku 20. století (Katholski posoł) a z let 2008-2010 (Serbske nowiny), jen dva př́klady jsou doloženy v beletristických textech z 2. poloviny 20. stol., srov.:

(11) Wě derje powědać, a ja móžu jemu hodźiny připosłuchać, ale Martu kopaše kóžde druhe słowo, a hněw nad »tajkim žwantorjenjom « jej ćěrješe čerwjenu krej mjezwoči. (1952, Jurij Brězan, Stara Jančowa)

Zatímco u příkladů dosud popsaných dominuje $\mathrm{e}^{24} \mathrm{v}$ těchto vazbách substantivum hněw, vyskytuje se v této skupině třikrát derivát rozhněwanosć, a to výhradně v novinách z let 2008-2010, např̀:

(12) Je to rozhněwanosć wolerjow nad politiku, jich protest abo tči snano wjace za tym? (2008, Serbske nowiny)

\section{Okrajové vazby se substantivy s kořenem -hněw-}

V korpusu jsou kromě toho doloženy tři příklady s dnes už zastaralou předložkou přre $+\mathrm{A}$, nejmladší z nich je v textu z roku 1976, nejstarší ze začátku 20. stol., např.

\footnotetext{
24 Jen ve třech př́íkladech jde o jiné substantivum, které je doplněné o vazbu vyjadřující sensum pomocí předložkové fráze: hněwnosć, hněwanje a rozhněwanje. Stejně jako všechny tři příklady se subst. rozhněwanosć, jsou i tyto př́klady doložené všechny v tisku z období po roce 1990 (Rozhlad, Serbske nowiny).
} 
(13) „Što, Messias wumrěł? Toho smy křižowali? Žónska, njebudź njerozomna!” a połny hněwa pře tajke blady a hłuposće woteńdźe do komorki. (1918, Katholski posot).

Vazba substantiva hněw s předložkou prećiwo $+\mathrm{D}$ je v korpusu doložena téměř výhradně v časopise Katholski posoł z let 1911-1920, př́kladů je zde 18. Jediný další příklad v jiném médiu je následující:

(14) Najbóle bolachu Krabatowe wuznamjenjenja dwanaće wysokich zastojnikow, kotřiž tohodla zapřimnychu surowy hněw, nic wšak přećiwo Krabatej, kotryž so jim mało strašny zdaše, ale přećiwo kralej samemu. (1956, Paul Nedo, Sorbische Volksmärchen, Bautzen)

Přestože je tato vazba zastoupena poměrně často, lze ji označit jako okrajovou, protože je zřejmě omezena na menší počet (resp. okruh) autorů.

Zcela okrajová je v korpusu vazba substantiva hněw s předložkou přez $+\mathrm{A}$, srov. jediný př́ílad:

(15) Jeho dalše słowa so zadusychu $\mathrm{w}$ jeho přesłapjenju nad Janowym njezajimom a w hněwje přez nanowej wusměšowacej woči. (1963, Beno Šołta, Statok bjez hospodarja)

Další vazba, která je v korpusu zastoupena jen dvakrát v nejmladších textech a pravděpodobně vznikla pod vlivem německé vazby Ärger (haben) mit, je vazba s předložkou $z+\mathrm{I}$ :

(16) A ja jej wšo wupowědam, wo Andreju, wo jeho pochadźe, wo hněwje z Maren, wo Elwirje a Měrćinje. (2008, Měrka Mětowa, Skónčnje 14. Za Sofjiu a Andreja)

Obě tyto okrajové vazby, zdá se, jsou ovlivněné německými vazbami s ärger-, kde je intenzita emoce menší: kontexty nedovolí interpretaci ve smyslu německého Wut nebo Zorn.

\section{Vazby adjektiv a participií s kořenem -hněw-}

V korpusu se nachází 840 (21,7 i. p. m.) adjektiv nebo participií s tímto kořenem. Často je lze chápat jako část predikátu, kde je spona (tvar slovesa ,být') elipticky vynechána. Adverbium hněwnjeje oproti tomu doloženo vzácněji (138;3,6 i.p. m.). Tato tendence by mohla také souviset $s$ kontaktem s němčinou, kde se adjektiva a adverbia často formálně neliší. Vazby s kopulou jsou doloženy rovněž - tady dominuje jako u slovesných tvarů (hněwać so apod.) pro roli sensum předložka na + A: być hněwny na čo/koho 'zlobit se na koho' (78 dokladů). Podobné vazby jsou časté i pro různá participia od sloves s kořenem -hněw-, nejčastěji rozhněwany. Poměrně vzácné (143 z celkem 840 adj. dokladů s kořenem -hněw-) 
jsou naopak doklady, v nichž adjektivum slouží jako př́idavné jméno upřesňující substantivum, např.:

(17) To budźeš stać před sudnym stołom Božim. - „Přisahaj; zakliwaj Jězusa!” woła hněwny a njemdry sudnik. (1916, Katholski posoł)

Podobně je tomu i u adjektiv a participií s kořenem -mjerz-. Naopak pro adjektiva s kořenem -złóst/ć- platí, že jsou užívána převážně ve funkci bližší charakterizace substantiva ve větě a méně často $s$ (elipticky vynechanou) sponou. U tohoto kořene je také počet skutečných adverbií výrazně větší (srov. pozn. 21). Pozoruhodné jsou ojedinělé tvary s dativem być hněwny komu:

(18) A z tajkim lesnym wóčkom na njeho pohladawši, pokročowaše: »Hněwny drje mi njebudźeće, hdyž tež młodemu zemjanej zbože přeju? [...]« (1875, Jakub Bart-Ćišinski, Zhromadźene spisy. 6. Proza, Budyšin 1972)

Tato vazba je doložena dvakrát (druhý př́íklad je v časopisu Wosadnik z roku 1979) a má opět paralelu v německém jm. böse sein.

Běžnější je vazba s předložkou dla $+\mathrm{G}$, která je typická zejména pro tisk z období po r. 2000 - jen 3 ze 14 př́íkladů pocházejí ze starších textů25, srov.:

(19) Tohodla sej burja husto přejachu, zo by djaboł wšěch tych knježkow sobu wzał. Čert, wěčnych skóržbow dla rozhněwany, wza wulki měch, styka do njeho telko knježkow, kelkož bě jenož móžno, a lećeše z nimi do Delnjeje Łužicy. (1959, Serbske powěsće. Wuběr za dźéći, Budyšin 2003)

Netypické jsou vazby s předložkou přećiwo $+\mathrm{D}^{26}$, oba doklady najdeme opět v časopise Katholski posoł ze začátku 20. stol., srov.:

(20) Zhromadźizna bě přećiwo němskim zapósłancam žałostnje rozhorjena a hněwna. (1913, Katholski posoł).

Už adverbium žałostnje 'hrozně' zde napovídá silnější intenzitě emoce, kombinace s adjektivem rozhorjeny 'rozčílený' ji podtrhává. $\mathrm{V}$ němčině takové vazbě i významu odpovídá např. Groll gegen jmdn hegen nebo Wut/Groll richtet sich gegen jmdn. (DUDEN).

Vazby s předložkou nad + I jsou v korpusu doloženy dvakrát, např.:

(21) Joho zwučena surowosć joho wopušći, byrnjež by hišće pokhmurjenje hladał, kaž hněwny nad swojej słabosću. (1914, Mikławš Bjedrich-Radlubin, Legendy a druhe powědančka)

25 Dva doklady pocházejí z roku 1920 z Lužickosrbské čítanky, a nelze tedy vyloučit, že příklady jsou ovlivněny purismem nebo vlivem českého $k v u ̛ l i$.

26 Srov. ale české hněv proti čemu (Svozilová et al. 2005, s. 82). Katholski posoł byl v této době pravděpodobně v redakci lužickosrbských kněží, kteří vystudovali v Praze. 
Druhý př́klad pochází z Serbskich nowin (2010). Dvakrát v období nejmladším (1989-2010) a jednou v roce 1957 jsou doloženy př́klady s předložkou prez $+\mathrm{A}$, srov.:

(22) Józef dźěše potom do města, chcyše hišće na banku po pjenjezy, wječor pak nochcyše zaso přińć. Přez to běch tróšku hněwna. (1989, Beno Budar, Mjez nami prajene)

Tyto méně často frekventované vazby ( $p \check{e} e z+\mathrm{A}$, nad $+\mathrm{I})$ by mohly opět být motivovány vlivem německého ärgerlich (über etw.) s o něco nižší intenzitou emoce. Ojedinělá - a omezená na adjektivní vazbu ${ }^{27}$ - je varianta s předložkou $z+\mathrm{G}$ :

(23) Překupc čuješe, zo bě jeho Leńš na łžach lepił, a bu z toho hněwny. (1959, Jurij Brězan, Christa. Trix. Robert a Sabina, Zhromadźene spisy 2, Budyšin 1966)

\section{Vazby s tranzitivními slovesy s kořenem -hněw-}

Sloveso hněwać a jeho prefigované deriváty (roz-, vzácněji $z a-, z-;$ v korpusu dohromady se simplexy 425×, tj. 11 i. p. m.) jsou ve valenčním slovníku uvedeny ve dvou sémantických skupinách (srov. výše): jako slovesa chování/pocitu (Meškank 2009, s. 338n.; v korpusu celkem $162 \times{ }^{28}$ ) nebo jako slovesa jednání/ účinek (ibid., s. 712; v korpusu celkem 263 prŕkladư ${ }^{29}$ ). Kromě u Meškanka zmíněných doplnění jsou ale pro sloveso jednání/účinek v korpusu doložena i další fakultativní doplnění, a to nejčastěji s prepozicí $z+$ I pro propositum $^{30}$, např.:

(24) Hdyž sebi zaspěwachmy Kocorowe spěwy, wón nam zanjese partije z Wagnerowych operow a chcyše nas z tym hněwać. (1983, Jan Cyž, Hdyž so młody na puć podaš. Dopomnjenki z časa dźéćatstwa a młodosće hač do apryla 1926)

Korpus obsahuje 56 takových příkladů, častěji se vyskytují s prefigovaným rozhněwać (sej) koho (35×) než u simplexu hněwać koho (21×). Vazba se vyskytuje velmi často v nejnovějším vydání Bible (Swjate pismo 2006; celkem $21 \times$ ) a jiných náboženských textech $(9 \times)$, ale i v dalších textech od konce 19. stol. až po nejnovější. Sémanticky se tato vazba liší od povrchově stejného hněvat se s někým a zlobit se s někým 'být rozhádán' a také je odlišná od vazby hněw/mjerzanja $z$ kim/

${ }^{27}$ Jinak je tomu u kořena -mjerz-: tam je doložena předložka $z+$ G dvakrát i se zvratným slovesem, srov. níže.

28 U této varianty dominuje simplex, předpona roz- je doložená $25 \times$, předpona $z a$ - třikrát. Sloveso zahněwać koho je doložené pouze v období mezi léty 1959 a 1964 u dvou autorů.

29 U této varianty je předpona $r o z$ - doložena v polovině př́ikladů (137×), prředpona $z a$ - třikrát a $z$-dvakrát. Obě tyto vzácné předpony jsou doloženy jednou na konci 19. století ve stejném textu, předpona $z a$ - pak v 60. letech 20. století a $z$ - jednou v časopise Wosadnik roku 1979.

30 Takto označuje Meškank (2009, s. 343n.) obdobné doplnění u slovesa mjerzać, srov. níže. 
čim, kde je význam bližší německému ärger2 'obtíž, problémy, otrava' (srov. příklady 32-34) a doplnění lze klasifikovat jako sensum. V prŕípadech, jako je (24), jde naopak o propositum (srov. níže a Meškank 2009, 343n.).

Okrajově se $\mathrm{v}$ korpusu vyskytuje i fakultativní vyjádření sensa u slovesa jednání/účinek rozněwać koho pomocí předložky na koho (3×), např.:

(25) Najradšo wšak by tež hišće tu wěc z Nowušom přednjesł, měješe pak tola za mudrišo, wo tym mjelčeć, dokelž bě to wot Jana zhonił a dokelž nochcyše nana na syna rozhněwać. (1963, Beno Šołta, Statok bjez hospodarja)

Další př̌edložková spojení ( $w$ čim, přez čo) jsou doložena jen dvakrát, resp. jednou.

\section{Vazby zvratných sloves s kořenem -hněw-}

U zvratného slovesa -hněwać so (celkem 1159 dokladů) 31 převažuje - stejně jako v jiných slovanských jazycích - fakultativní vazba s na + A (448×), kterou také zmiňuje Meškank (2009, s. 339) jako jedinou možnost. Vyskytují se i další vazby pro vyjádření sensum, nejčastěji dla + G (19x), přez + A (5×), nad + I (15×) a $z+\mathrm{I}(5 \times)^{32}$. V dalších sedmi př́ípadech je sensum vyjádřeno dvěma předložkovými frázemi na koho a dla čeho, jednou je doložena okrajová vazba rozhněwać so přećiwo komu. Nejširší škálu vazeb vykazuje simplex hněwać, prefixace rozhněwać so je doložena s předložkami na, dla, nad, $z$ a précíwo.

Vazba přez + A, kritizovaná v metajazykové publikaci (viz výše), je doložena pouze se simplexem, a to od 70 . let 20 . století po nejnovější texty. Všechny doklady nacházíme v beletristických textech, srov.:

(26) Njehněwaj so přez tutón jara dołhi list dźensa. (1978, Beno Budar, W susodstwje makrelow)

(27) Njewědźeše, přez čo so bóle hněwaše: Zo bě wo někotre punty přećežka abo zo bě bratr za tym přišoł, zo so jej Tobias lubješe. (2007, Serbska protyka 2008/ red. Alfons Frencl)

Doporučovaná alternativní vazba (kromě preferované a zároveň nejčastější vazby $n a+$ A) s předložkou nad + I jako ekvivalent pro německé sich über etw./jn. ärgern je oproti tomu doložena i u prefigovaného slovesa, a to už od konce 19. století, a zároveň je zastoupena i v nejmladších textech všech žánrů, srov.:

31 Zvratné sloveso je rovněž nejčastěji doložené jako simplex. Kromě toho je běžné s prefixem roz- $(233 \times)$, ale i s dalšími: $z a-(4 \times)$, na- $(3 \times)$, dowu- $(1 \times)$, po- $(1 \times)$, wot- $(1 \times)$, wu- $(1 \times)$, poroz$(1 \times)$. Dále je doložen jeden prŕíklad se sufigovaném derivátem hněwkać so.

32 Prefigované sloveso pohněwać je v obou př́kladech spojeno se zastaralou předložkou pře a akuzativem, oba př́klady jsou doložené $\mathrm{v}$ Katholském posolu 1918. Tato předložka je jinak doložena už pouze jednou se simplexem v beletristickém textu z roku 1958. 
(28) Wobskoržuja tež włastojcžki, zo pcžoły morja. Něchto, kiž je nad tym so jara rozhněwał, je jich hnězda z młodymi pschepytował a [...]. (1887, Serbski hospodar)

(29) Druzy hněwaja so nad šlinkami, kotrychž pak lětsa pozdaću telko njeje. (2010, Serbske nowiny).

Stejný výrok platí i pro o něco častěji doloženou vazbu s předložkou $d l a+G$, srov.:

(30) »So rjeńša, njezrudzej, što hněwaš so dla šćuwanja? Swět toho hódny njej, [...]« (1850, Handrij Zejler, Zhromadźene spisy. V. Budyšin 1984)

(31) Wona so tež najmjeńšeje straty dla spěšnje rozhněwa a kaž zazłobjene dźěćo hnydom biješe. (2001, Wobraz ze skibami. Antologija serbskeje prozy)

Lze tedy shrnout, že pouze jedna vazba se zkoumaným slovesem je nová, a to přez + A. Právě u této vazby je pravděpodobné, že se jedná o ekvivalent německého ärger v obou významech, jenž se v němčině pojí s über, a ne auf 'na'. Významy kořenu -hněw-, které jsou bližší intenzivnější emoci, oproti tomu často odpovídají i německým kořenům Wut a Zorn, z nichž Wut se může pojit s předložkou auf s akuzativem - vidíme zde strukturu paralelní k slovanskému hněv na koho, která pravděpodobně pomáhá tento typ zachovat.

\section{Kořen -mjerz-}

Tento kořen je v korpusu doložen $2281 \times$, tj. 58,8 i. p. m. Na rozdíl od kořene -hněw- je zde podíl substantivních tvarů ${ }^{33}$ nižší, což souvisí s tím, že se jedná původně o slovesný kořen a vedle dějových substantiv jen vzácně nacházíme další deriváty: mjerzanje, roz-, za-mjerzanje, mjerzatosć, nje-, roz-mjerzatosć, roz-, za-mjerzanosć.

\section{Nejčastější vazby substantiv s kořenem -mjerz-}

Substantiva (celkem $577 \times$ ) se vyskytují ve verbonominálních spojeních, nejčastěji se slovesem měć, méně často i se slovesem być, a v dalších frazémech. Příkladů, $\mathrm{v}$ nichž je doplnění jednoznačně napojeno na substantivum, je v korpusu celkem 82. Jinak než u kořene - hněw - je zde převaha vazby (měć) mjerzanja $z \mathrm{kim} / \mathrm{čim}$ $(53 \times)$, doložené v textech ze všech sledovaných období, např.:

(32) Wy prajiće, zo ma wšak z čeledźu hary a mjerzanja wjace dyžli dosć. (1891, Jan Radyserb-Wjela, Bitwa pola Budyšina, Budyšin 1971)

(33) Wón ma dosć mjerzanja z tymi Budyskimi wučencami. (1966, Jurij Wjela, Robotow pak njebě kónc)

33 V analýze se nezabývám deriváty, které označují osobu, např. mjerzak. 
(34) Nawopak, wone małe wšědne kałaćiki kaž [...] abo mjerzanja $\mathbf{z}$ dźéćimi a wšelke tamne zwjetša njetrěbne rozkory su „strašne”. (2002, Serbska protyka 2003/ red. Alfons Frencl)

Tato vazba odpovídá německému Ärger (haben) mit etw./jmd., která je poměrně frekventovaná - stejně jako vazba Ärger (haben) wegen etw./jmdm. Tato druhá vazba má v hornolužickém korpusu rovněž svůj ekvivalent: měć mjerzanja dla čeho/koho $(18 \times)$. Stejně jako u kořenu -hněw- je předložka dla $+\mathrm{G}$ zastoupena častěji v publicistických textech $(14 \times)$, a to především v těch nejmladších $(10 \times)^{34}$. Zároveň je ale doložena i v textech beletristických, a to už v 19. století, srov.:

(35) [...] mam mjenujcy zaplacaneho wojerstwa dla wjele běhanja a staranja a mjerzanja, tak zo mi njeje móžno, něšto hódne z měrnej krewju napisać. (1885, Jakub Bart-Ćišinski, Zhromadźene spisy 10. Listowanje, Budyšin 1975)

Kontext i kolokáty běhanja a staranja poukazují na to, že se substantivum užívá ve smyslu německého ärger2 'starost, povinnost, otrava, problémy'.

Mezi substantivy s kořenem -mjerz- je 6 prŕikladi̊ s předložkou na $+\mathrm{A}$, a to v textech z let 1912 až 1983, např̀.:

(36) Z kóždym dźěše mjerzanje sobu, mjerzanje na Dypornaka a na knježnu Brojerjec, byrnjež bě wona chcyła. (1974, Jan Wornar, Dypornak ma ptačka)

\section{Ojedinělé vazby substantiv s kořenem -mjerz-}

Další vazby jsou u substantiv s tímto kořenem doloženy jen velmi ojediněle: nad + I $(2 \times)$ a př̀z + A (1×). Obě lze přiřadit k německé vazbě Ärger über etw./jmdn. a obě jsou doložené v mladších textech ${ }^{35}$ :

(37) Hordosć na ryzy swójsku swojoraznosć, wjeselo nad jeho připóznaćom a mjerzanje přez zwjetša wulki nawal cuzych so wurunaja. (1996, Měrćin Wałda, $N a$ łožki nalěća)

(38) A kelko wě powědać, wšědne wobkedźbowanja, małe podawki, swoje wjesela a mjerzanja nad wobydlerjemi tuteje archi. (1993, Rozhlad)

34 V jednom z těchto př́padů jde o kombinaci dvou vazeb: $z+\mathrm{I}$ a dla $+\mathrm{G}$.

35 Vazba nad + I je navíc doložena ve starším publicistickém textu - je to doklad neobvyklý tím, že zde vystupuje jediný doklad prefigovaného substantiva (rozmjerzatosć) s valenční vazbou a navíc jediný doklad tohoto substantiva vůbec. Derivát bez prefixu mjerzatosć je doložen pětkrát v beletristických textech od 19. století až do 80 . let 20. století - bez valenčních doplnění. Derivát s tímto sufixem je tedy obecně okrajový. 


\section{Vazby adjektiv a participií s kořenem -mjerz-}

Korpus obsahuje 545 dokladů s adjektivy (mjerzaty) nebo participii (mjerzacy (so), mjerzajo, roz-, za-, ze-zamjerzany) se sledovaným kořenem, přičemž tvary participií silně převažují. Příkladů, v nichž jsou tyto predikáty doplněny údajem o sensu hněvu, je $\mathrm{v}$ korpusu dohromady 12. Zastoupena jsou participia prézenta aktiva (mjerzacy $4 \times)$ v adj. užití, adjektivum mjerzaty $(1 \times)$ a participia préterita pasiva $($ roz- $5 \times / z a-$ mjerzany $3 \times)$ - pojí se s podobnou škálou vazeb jako substantiva: dla $+\mathrm{G}(4 \times), n a+$ $\mathrm{A}(7 \times), z+\mathrm{G}(3 \times)$, ojediněle i pře $+\mathrm{A}(1 \times)$ a prée $+\mathrm{A}(1 \times)$. Uvádím některé prŕklady:

(39) Pruwuj so: Dopominam so, zo je mje dla štó zły abo mjerzacy byl ( staršej, bratřa, sotry, wučerjo, přećeljo)? (1979, Wosadnik)

(40) A dokelž sym zhonił, zo sy Ty wbohi tež w poslednim času často był chorowaty a na njeluboznosće swěta mjerzacy, sym so rozsudźił, [...] (1909, Jakub Bart-Ćišinski, Zhromadźene spisy 13. Listowanje, Budyšin 1978)

(41) »Aj, to móhł čłowjek $\mathrm{z}$ woknom won zlećeć!« zawoła direktor mjerzaty pře tajku twjerdošijnosć. (1875, Jakub Bart-Ćišinski, Zhromadźene spisy 6. Proza, Budyšin 1972)

(42) Rozmjerzany přez hłupe zemske prašenje zasyčach na ambosu. (1983, Jurij Koch, Nawrót sonow)

Zastaralá předložka pře je opět doložena ve starém textu, naopak přez je doloženo $\mathrm{v}$ textu poměrně mladém. Jinak se obě předložky vyskytují jak s neprefigovanými, tak i s prefigovanými tvary, ve starších i v mladších textech.

$\mathrm{O}$ něco častěji $(3 \times)$ je $\mathrm{v}$ této roli doložena vazba s předložkou $z+\mathrm{I}$, srov.:

(43) Prescher njeměješe słabomyslneho kedźbu, bě mjerzaty $\mathbf{z}$ nowych nazhonjenjow. (1963, Pawoł Kmjeć, Pawoł Grojlich, $Z$ wusadnym za blidom)

Významným rozdílem oproti kořenu -hněw-a jeho adjektivům je výskyt některých konstrukcí, v nichž je experiencer vyjádřen dativem $(6 \times)$ nebo předložkou $z a+$ A $(8 \times)$, zatímco sensum je subjektem věty ${ }^{36}$, srov.:

(44) Mjerzace [sic!] funkcionaram wšehomócneje Komunistiskeje strony Čěskosłowakskeje (KSČ) bě podawk lěta 1986. (2006, Serbske nowiny)

(45) Wosebje njedosahace pak bywa informowanje pasažěrow, štož je chětro mjerzace za turistow, njewuznawacych so w hoberskim měsće. (2006, Serbske nowiny)

Obě konstrukce jsou doloženy téměř výhradně v publicistických textech ${ }^{37}$, konstrukce s dativem je poprvé doložena r. 1872, konstrukce s předložkou $z a+$ akuzativ r. 1911.

36 Srov. naopak př́klad (18) s adjektivem hněwny a sponou, kde je patiens v dativu a agens subjektem věty!

37 Jediný doklad v nepublicistickým textu jsem našla ve vydání dopisů B. Krawce z roku 1920 (Achim Brankačk, Listowanje Bjarnata Krawca z Arnoštom Muku, Měranku Lešawic a Michałom 


\section{Vazby tranzitivních sloves s kořenem -mjerz-}

Sloveso mjerzać je u Meškanka (2009, s. 343n.; 730) popsáno stejně jako hněwać - jako sloveso chování/pocitu s rolemi experiencer (akuzativní objekt) a sensum (subjekt) anebo jako sloveso jednání/účinek s agentem (subjekt) a patientem (akuzativní objekt). Rozdílné v popisu však je, že Meškank u mjerzać jako slovesa jednání/účinek zmiňuje možnost doplnění proposita pomocí předložky $z+\mathrm{I}$, jak jsem ji našla i v korpusových př́kladech pro sloveso hněwać (srov. výše). Zvratné sloveso mjerzać so je u Meškanka (2009, s. 344) rovněž popsáno podobně jako hněwać so - jako sloveso chování/pocitu s existorem (subjekt) a sensem (na + A), navíc je zde však zmíněna varianta s doplněním přez + A. Tyto rozdíly v popisu valence u Meškanka by mohly dokládat drobný rozdíl ve významu - přestože Pohončowa et al. (2009) je popisuje jako synonyma (srov. výše) ${ }^{38}$.

V korpusu je 420 prŕklado̊ se slovesy s kořenem -mjerz-, tj. 10,8 i. p. m. Převažuje simplex, vyskytují se zde ale i prefigovaná slovesa roz- $(39 \times), z a-(19 \times)$, po- $(4 \times), z$-mjerzać $(1 \times)$. Sloves jednání/úćinek s tímto kořenem je celkem 140 , $z$ toho je 12 př́kladů ${ }^{39} s$ doplněním $z+\mathrm{I}$ ( $3 \times$ s prefigovaným slovesem rozmjerzać). Doloženy jsou ve všech obdobích a žánrech textů, např.:

(46) Hólcy pak hišće pijachu a hdys a hdys Jurja $\mathbf{z}$ wobwěšenym mjerzachu. (1880, Hronow a druhe powědančka, Budyšin 1967)

(47) Maćeri so to njelubješe: „Za to njejsmój tebi lampku dariłoj, zo by z njej holcy mjerzal." (2007, Widźu nana, widźu mać. Swójbne dopomnjenki)

Vazba $d l a+G$ je s tímto kořenem doložena jen jednou v časopise Płomjo z nejmladšího období:

(48) Jeho sobušulerjo jeho dla toho mjerzachu. (2009, Płomjo)

$\mathrm{V}$ jednom př́padě se vyskytuje vazba přez $+\mathrm{A}$ :

(49) Hdyž je něchtó přez swoje njepřemyslene jednanje druheho člowjeka rozmjerzal, praji so wo nim, zo je sej pola druheho do črjopika stupił. (2009, Anatolij Iwčenko, Sonja Wölkowa, Wo wćipnych Jěwach a nócnych hawronach)

Velmi neobvyklý je také jediný doklad s vazbou na + A. Jedná se o citát ze starého dopisu v populárněvědeckém časopise, srov.:

Nawku, Budyšin 2001; Lětopis 48, Wosebity zešiwk).

38 Obě publikace - Pohončowa et al. (2009) a Meškank (2009) - vyšly ve stejném roce, autoři tedy nemuseli o vzájemně odlišných hodnoceních vazby přez + A nutně vědět.

39 Tato vazba se tedy vyskytuje u více než $8 \%$ sloves jednání/účinek, což je výrazně méně než u slovesa jednání/účinek -hněwać-, kde se objevuje v 55 příkladech z 262, tj. zaujímá něco přes $20 \%$. Je také nápadné, že podíl sloves jednání/účinek u kořene -hněw- je větší, u kořene -mjerz- je to obráceně. 
(50) Na přikład pisa Radyserb Muce w nowembrje 1899: „Česćeny knježe! Luby serbski přećelo! Njebudź Wam dźiwno, hdyž praju, zo mje na našu Maćicu mjerza. $\mathrm{Na}$ Časopis njepraju hórkeho słowa, tón chwalu. Ale što dawa Maćica za powšěnych ludźi? (1997, Rozhlad)

Ani v kontextu (dále $\mathrm{v}$ textu) nelze najít konatele, který by někoho nahněval - podobnou neosobní konstrukci bez subjektu jsem s tímto kořenem ani s částečně synonymními kořeny nenašla.

\section{Vazby zvratných sloves s kořenem -mjerz-}

Zvratná slovesa s kořenem -mjerz- jsou doložena 739×, tj. 19,1 i. p. m. I zde silně dominuje simplex, z prefixů jsou doloženy roz- $(68 \times)$, za- $(17 \times)$, po- $(3 \times)$. Zdaleka nejčastější je vazba na + A pro sensum $(245 \times)$ - ve všech textech a obdobích. $\mathrm{V}$ pěti př́kladech z nich se navíc vyskytuje vazba $d l a+\mathrm{G}$, srov.:

(51) Sym so skoro na njeho dla tak pesimistiskeho wuprajenja mjerzał... Čehodla měli Serbja zahinyć? (1923, Adolf Černý, Serbske wobrazki / přełožił a zawod napisał Ota Wićaz)

Vazba $d l a+G$ je u tohoto slovesa doložena i jako jediná předložková fráze, a to v 13 dalších př́íkladech, především z období nejmladšího ${ }^{40}$, srov.:

(52) Najprjedy chcych so dla wysokich płaćiznow za parkowanje mjerzać, ale dokelž běchu wšitcy přezjedni, zo dźemy pěši dale, zalutowachmy sej wudawki za konjace wozy. (2008, Achim Mič, Njebjesam blisko. Z dźenika serbskeho alpinista Do hornjoserbšćiny přełožił Alfred Měškank, Budyšin)

(53) „A njemjerzaj so dla toho Žura tak jara”, wona praji, [...] (2008, Paternoster. Teksty młodych awtorow 3)

Podobně častá je vazba nad + I s tímto slovesem (celkem 10×), srov.:

(54) Potajnstwo ležeše ćežko w mysłach, a wón mjerzaše so nad hłupej Brigitu, Wona jenož Čuka hidźi, dokelž ju njeje za połnu měł. (1962, Jurij Krawža, Módre listy)

Tato vazba je doložena u slovesa s tímto kořenem až z období po r. 1945 (nejstarší příklad je z roku 1952) a přetrvává do nejnovějšího období. Častější, a rovněž typická

40 Z toho je 8 př́ikladů doloženo v publicistických textech po roce 1990 a tři další najdeme $\mathrm{v}$ textech přeložených $\mathrm{z}$ češtiny nebo němčiny publikovaných od roku 1957. I dva originální beletristické texty s takovým dokladem jsou poměrně mladé: viz př́klad (53) a doklad v textu Młynkowé z roku 1965. Je zajímavé, že je předložka dla v beletristických textech nebo dopisech častěji anteponována, zatímco v publicistických textech se častěji postponuje. 
pro nejmladší texty je vazba prěez $+\mathrm{A}(26 \times)$, a to zejména v mladších beletristických ${ }^{41}$ textech. Nejstarší př́klad je z roku 1976, další z roku 1978, srov.:

(55) A hižo so přez sebje mjerzach, přez te hłupe ganzorstwo, přez samaritnosć, kotruž naš čas njetrjeba, naš porjad. (1978, Jurij Koch, Wosamoćeny Nepomuk: lubosćinske powědančka)

Další vazby se vyskytují jen ojediněle: prećiwo $+\mathrm{D}(1 \times)$ je doloženo v textu ze začátku 20. století, vazby $z+\mathrm{I}(3 \times)$ a $z+\mathrm{G}(2 \times)$ naopak $\mathrm{v}$ textech novějších, od 60. let 20. století.

\section{Závěr}

$\mathrm{Na}$ závěr porovnám data obou kořenů mezi sebou $\mathrm{z}$ několika hledisek. Z následujících grafů lze vyčíst tyto výsledky:

1. Kořen -mjerz- je v poměru ke kořenu -hněw- relativně čím dál tím častější, srov. následující graf ${ }^{42}$ :

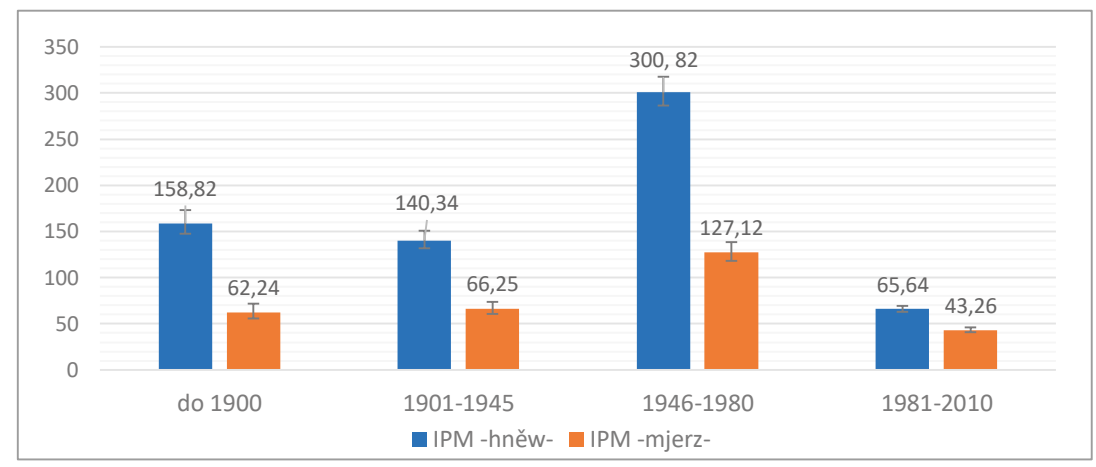

Graf 1. Výskyt kořenů -hněw-a -mjerz- v různých obdobích

Graf 1 ukazuje, že v textech 19. stol. je poměr mezi kořeny -hněw- a -mjerzpřibližně 3:1, v obdobích mezi léty 1901 a 1980 přibližně 2:1, v posledních 30 letech zhruba $1,5: 1^{43}$.

2. Predikáty se substantivem s-mjerz-a se substantivem s-hněw- mají tendenčně odlišný vzor použivání: Graf 2 ukazuje výrazný rozdílv poměrech mezi nejčastější

41 Z časopisů je tato vazba doložena téměř výhradně v dětském časopisu Płomjo (2007-2009), jeden doklad jsem pak našla v odborném časopise Serbska šula (2009).

${ }^{42} \mathrm{~V}$ grafech jsou všechny významy/role doplnění s předložkou $z+\mathrm{I}$ shrnuty.

43 Výrazně nižší výskyt obou kořenů $\mathrm{v}$ posledním období souvisí pravděpodobně $\mathrm{s}$ tím, že korpus obsahuje velký počet publicistických textů z tohoto období, zatímco v předchozím období (1946-1980) je jich zastoupeno velmi málo. Pro obě období je v korpusu jedna edice celé Bible. 
vazbou na + A a ostatními vazbami u substantiv obou kořenů. U sloves jsou poměry naopak podobné.

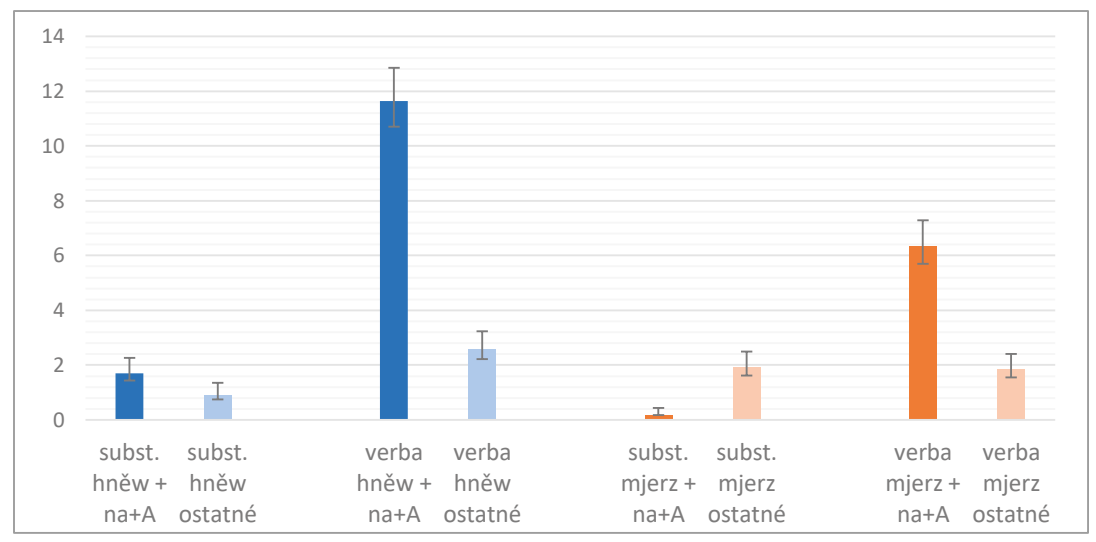

Graf 2. Vazby na + A a ostatní vazby u substantiv a verb obou kořenů

3. Většina málo doložených vazeb nemá statisticky analyzovatelný výskyt, ovšem na konkrétních příkladech je vidět, že valence může přispět k specifikaci významu predikátu. Zejména $\mathrm{v}$ mladších textech je zřejmá snaha diferencovat významy obou kořenů - pro takovou interpretaci mluví i tendence méně často používat nejběžnější varianty hněw na + A a hněw nad + I oproti všem ostatním variantám včetně těch $s$ kořenem -mjerz-, které jsou statisticky podobně časté v obou obdobích, srov. Graf 3.

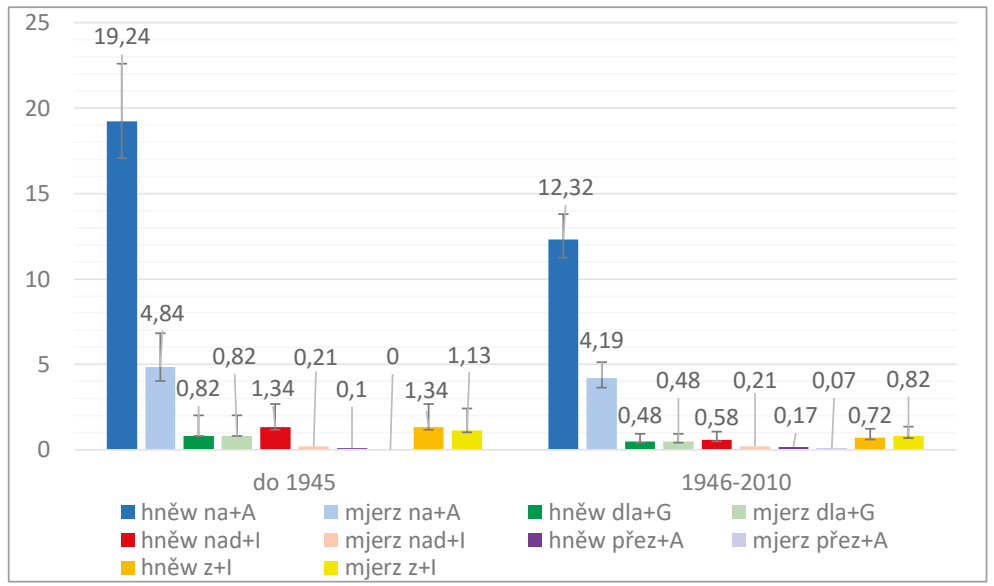

Graf 3. Výskyt vazeb u kořenů - hněw- a -mjerz- před r. 1945 a po něm v i. p. m.

V Grafu 4 srovnávám výskyty valenčních vazeb u obou kořenů v poměru k celkovému výskytu obou kořenů pro všechny predikáty dohromady. Je vidět, 
že největší počet dokladů v korpusu nemá valenční doplnění. Mezi těmi, které doplnění mají, dominuje vazba na + A. Podíl ostatních vazeb je u kořene -mjerznicméně větší - s jednou výjimkou: předložkou nad + I, která je u kořenu -mjerzmálo doložená jak ve starých, tak i v mladších textech.

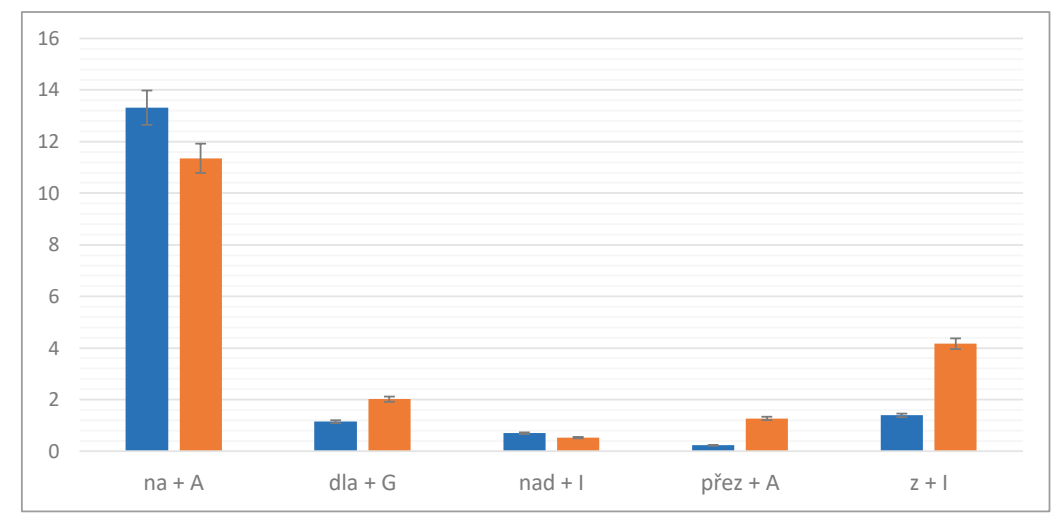

Graf 4. Valenční vzory: procentuální podíl na celkových počtech výskytů kořenů

\section{Bibliografie a prameny}

Brankačkec, K. (2017). Valenční vazby ekvivalentů německého (sich) an etw. gewöhnen v korpusech Diakorp, Hotko a Dotko (ČNK), Prace Filologiczne, LXX, 105-127.

Brankačkec, K., Kocková, J. (2020). Main Slavonic Predicates with the Root "-gnev-". A corpus-based comparison of Russian, Czech and Sorbian. In: E. Gutiérrez Rubio et al. (eds.), Contributions to the 22nd Annual Scientific Conference of the Association of Slavists (Polyslav) (36-45). Wiesbaden: Harrassowitz.

Brankačkec, K. et al. (2019). Lehnprägungen im Tschechischen und Sorbischen. Eine diachrone, korpusbasierte Analyse ausgewählter Lexeme und Präfixe. Berlin: Peter Lang.

Daneš, F., Hlavsa, Z. (1987). Větné vzorce v češtině. Praha: Academia.

Engel, U. (1996). Deutsche Grammatik, 3., korrigierte Aufl. Heidelberg: Julius Groos Verlag. Faska, H. (ed.). (1998). Serbšćina. Opole: Uniwersytet Opolski - Instytut Filologii Polskiej.

Faßke, H. (1981). Grammatik der obersorbischen Schriftsprache der Gegenwart. Morphologie. Bautzen: Domowina.

Jentsch, H. et al. (1989/1991). Deutsch-obersorbisches Wörterbuch. Němsko-hornjoserbski słownik I-II. Bautzen: Domowina.

Kaczmarska, E. (2019). Metody ustalania ekwiwalentów czasowników wyrażających stany emocjonalne $w$ przekładzie czesko-polskim na materiale z korpusu równoległego InterCorp. Warszawa: Wydział Polonistyki Uniwersytetu Warszawskiego. 
Kolářová, V. et al. (2020). Nom Vallex I. Valenční slovník substantiv. Praha: Ústav formální a aplikované lingvistiky.

Kysel'ová, M. (2017). Medzi konaním a dianím. Sémantické aspekty verba a valencia. Prešov: Filozofická fakulta Prešovskej univerzity v Prešove.

Lopatková, M. et al. (2016). Valenční slovník českých sloves VALLEX. Praha: Univerzita Karlova, Nakladatelství Karolinum.

Meškank, T. (2009). Aussagenstruktur im Sorbischen. Untersuchungen zur Syntax und Satzsemantik. Bd. I und II. Hamburg: Verlag Dr. Kovač.

Mikołajczuk, A. (1999). Gniew we współczesnym języku polskim. Warszawa: Energeia.

Mluvnice 3 (1987). Daneš, F. et al., Mluvnice češtiny 3. Skladba. Praha: Academia.

Pohončowa, A. et al. (2009). Z labyrinta serbšćiny. Bjesady wo rěči. Budyšin: Domowina.

Schuster-Šewc, H. (1973). Zur gesellschaftlichen Bedingtheit standardsprachlicher Prozesse im Bereich des Westslawischen, Zeitschrift für Slawistik, XVIII, 2 (Beiträge für den VII. Internationalen Slawistenkongreß Warschau 1973), 213-226.

Svozilová, N. et al. (2005). Slovník slovesných, substantivních a adjektivních vazeb a spojení. Praha: Academia.

Trnka, R. et al. (2018). Components of cultural complexity relating to emotions: A conceptual Framework, New Ideas in Psychology, 51, 27-33.

Wallis, S. (2013). Binomial Confidence Intervals and Contingency Tests: Mathematical Fundamentals and the Evaluation of Alternative Methods, Journal of Quantiative Linguistics, 20, 3, 178-208. https://www.tandfonline.com/doi/full/10.1080/09296174.20 13.799918

Wierzbicka, A. (1995). Adjectives vs. verbs: the iconicity of part-of-speech membership. In: M. E. Landsberg (ed.), Syntactic Iconicity and Linguistic Freezes: The Human Dimension (223-245). Berlin: Mouton de Gruyter.

Wölke, S. (2005). Geschichte der sorbischen Grammatikschreibung. Bautzen: Domowina.

DUDEN - Dudenredaktion (o. J.):

„Ärger” Duden online. https://www.duden.de/rechtschreibung/Aerger (28.7.2020)

„Groll” Duden online. https://www.duden.de/rechtschreibung/Groll (28.7.2020)

„Wut” Duden online. https://www.duden.de/rechtschreibung/Wut (28.7.2020)

VALBU - Valenzwörterbuch deutscher Verben. In: Institut für Deutsche Sprache: „Systematische Grammatik”. Grammatisches Informationssystem grammis., DOI:10.14618/ grammatiksystem https:/grammis.ids-mannheim.de/systematische-grammatik/2912

HOTKO: Obersorbisches Textkorpus, Verze 1 z 6. 3. 2013. Serbski institut Budyšin / Ústav Českého národního korpusu FF UK, Praha 2013. http://www.korpus.cz, http://www. serbski-institut.de/cms/os/48/hornjoserbski 
ABSTRAKT: Článek se zabývá vývojem valence predikátů vyjadřujících negativní emoce v hornolužické srbštině. Na základě korpusu Hotko porovnává škálu významů dvou nejčastějších a do značné míry synonymních kořenů -hněw- a -mjerz-. Data ukazují, že kořen -mjerz- je v mladších textech častější a že častěji pokrývá emoce nižší intenzity než kořen -hněw - Specifický význam jednotlivých predikátů může být $\mathrm{v}$ textech upřesněn mj. právě různými valenčními doplněními, která často mají paralelní strukturu $s$ podobným významem $\mathrm{v}$ němčině $\mathrm{i} v$ češtině.

\title{
WALENCJA PREDYKATÓW WYRAŻAJĄCYCH „HNĚV” [GNIEW] W JĘZYKU GÓRNOŁUŻYCKIM
}

\begin{abstract}
ABSTRAKT: Artykuł dotyczy rozwoju walencji predykatów wyrażających negatywne emocje w języku górnołużyckim. Opierając się na korpusie Hotko, porównuję zakres znaczeń dwóch najbardziej powszechnych i w dużej mierze synonimicznych rdzeni -hněwi -mjerz-. Dane pokazują, że rdzeń -mjerz- występuje częściej w młodszych tekstach i częściej obejmuje emocje o niższym natężeniu niż rdzeń -hněw-. Specyficzne znaczenie poszczególnych predykatów można określić w tekstach m.in. poprzez różne dopełnienia walencyjne, które często mają strukturę równoległą o podobnym znaczeniu w języku niemieckim i czeskim.
\end{abstract}

